\title{
City Branding Strategy on the Evaluation of Tourism Destination Problems in Rural Area (Evidence from Pasuruan City, Indonesia)
}

\author{
Yusuf Risanto*, Ida Yulianti \\ Department of Management, Faculty of Economics and Business, University of Brawijaya, Malang, Indonesia
}

\begin{abstract}
This research find the essential problems of tourism destinations in rural area in Pasuruan City, Indonesia. Based on the phenomenology method and using an open questionnaire, researcher make a deep interview with manager of 10 tourism destinations in Pasuruan city relating with their condition. All of the tourism destinations sample in this research represent four tourism destinations categories includes natural, cultural, agricultural and special destinations. In general the essential problems was meet by most of the tourism destinations are poor management system, unspesific additional facilities, and no innovative marketing strategy. In the evaluation of this problems, city branding strategy is offered to cover a comprehensive solution. The main dimensions of city branding strategy for this problems are green space branding, identifiable image and positive brand experience.
\end{abstract}

Keywords: City Branding, Rural Area, Tourism Destinations.

\section{INTRODUCTION}

Tourism is the essential sector to improve economic condition in certain region. However, tourism should be integrated with other sectors to work together in order providing good supplement facilities such as qualified hotel, good transportation and positive government regulation. Place marketing and the development of destination brands has become strategic tools all over the world due to a growing competition among destinations [1]. Indonesia as one of the most popular destination has a particular report relating tourism contribution in national foreign exchange that gaining to US\$ 10 billion in 2014 [2]. The finding of previous research also describes that tourism sector gives a significant contribution for economic development such as increasing job opportunities, regional income and foreign exchange, and the equality of economic development [3]. Parallel to these conditions, Indonesian government tried to introduce tourism destination through decentralized strategy which giving an authority to province government managing their region.

Based on Indonesia Government Law No. 23 of 2014, it is described that each aoutonomy region has the authority to manage their activities in order to achieve economic welfare. In that case, most of the tourism destination in Indonesia is managed by province or state government.

\footnotetext{
${ }^{*}$ Correspondence address: Ida Yulianti

Email : ida_yulianti@ub.ac.id

Address : Mayjen Haryono No. 165, Malang 65145
}

In general, each destination are located in different area such as urban area and rural area which different catergorized such as natural destination and also modern destination. Most of the cities in Indonesia are categorized as urban area that second only to the rural area. Around three of five Indonesia citizen stay in rural area [4]. Therefore this research concern about developing tourism destination in Indonesia particularly in rural area. Rural area refer to the the certain area having low population and consist of the citizen doing an agriculture business. Rural area is also defined as a geographic area that is located outside cities and towns [5].

This research conducted an observation of tourism destination in Pasuruan city which is one of the rural areas in East Java, Indonesia that consisting of 24 subdistrict and 341 villages. In Pasuruan city, most of the citizens are farming $(33.98 \%)$, and then followed by industrial, tourism, and others sector with respective figures of $24.69 \%, 17.79 \%$ and $23.54 \%$ [6]. There are some tourism destinations in Pasuruan that categorized as popular destination in Indonesia such as Mount Bromo, Safari Indonesia Zoo, and Kaliandra Sejati and also unpopular destination such as Kakek Bodo Waterfall, Jawi Temple, Banyu Biru Natural Water Park, and so on. Mount Bromo is one of the popular destination in Indonesia visited more than 550,000 visitor in 2014 from Indonesia and overseas. However, another destination such as Jawi Temple is visited only around 15 people each day.

The contradictive condition among tourism destinations in one city indicates unappropriate 
city branding in that area. Some of the researcher mentions that city branding has similar concept of place branding. Despite destination branding, the government has to consider about their city reputation. More and more towns, cities, regions, and countries are investing in branding campaigns in order to establish a reputation for themselves, and to have a competitive edge in today's global market [7]. Place branding concentrates on creating a brand management system focused on the identity [8], and distinctive and definitive characteristics [9] of a particular place [10]. To sum up, this research has an intention to explore the fundamental problem of tourism destinations in Pasuruan city and also provide the city branding strategy based on research object condition.

\section{THE IMPORTANCE OF BRANDING IN TOURISM DESTINATION}

Branding as the potential strategy to improve popularity of tourism destination was introduced in 1998 by Annual Conference of Travel and Tourism Research Association. Every destination must be preparing the destination brand in which defined by the name, symbol, logo, word mark or other graphic that both identifies and differentiates the destination [11]. The proper branding strategy significantly contribute to the popularity of host destination as the unique destination [12]. The core of destination branding is to build a positive destination image that identifies and differentiates the destination by selecting a consistent brand element mix [13]. Destination branding can be defined as a way to communicate a destination's unique identity by differentiating a destination from its competitors [14]. Previous studies argue that brand identity and brand image are critical ingredients for a successful destination $[13,15,16]$. The image of a place is also an important asset. It emphasized that the image itself is the beginning point of tourist's expectation, which is eventually a determinant of tourist behaviors [17]. Destination image is a critical stimulus in motivating the tourist [13]. It is likely to be a critical element in destination choice process, irrespective of whether the image is truly representative of what a place has to offer or not [18]. Previous study also explained that image building is the former step, but there still remains a critical later step: the brand identity [13]. Consistent brand elements reinforce each other and serve to unify the entire process of image formation and building, which in turn contributes to the strength and uniqueness of brand identity.

\section{THE IMPORTANCE OF CITY BRANDING}

The essential function of city branding is undoubtable having more advantage for related city. In order to build city branding, it is needed to create a positive brand of each destination in that area. Its proven by some countries such as Australia, Brazil, Argentina and Spain have been apply place branding strategy. The destination brand building concept has not only been limited to the countries; it has also taken place in the different regions and cities [1]. The increasing number of visitor and boardening tourism destination have been influenced by the succesful of branding destination [19]. Comprehensive definition of a place brand a network of associations in the consumer's mind based on the visual, verbal, and behavioral expression of a place, which is embodied through the aims, communication, values, and the general culture of the place's stakeholders and the overall place design [20]. To manage place branding strategy, it needs good collaboration among stakeholders such as consumers (local people, employees of local organizations and targeted visitors), primary services (services at the heart of the core brand, for example, retailers, hotels and events), secondary services (brand infrastructure relationships) and the media (marketing communication channels advertising, publicity and public relations and organic channels arts and education) [21].

\section{MATERIAL AND METHODS \\ Research Method}

This research used qualitative method based on the phenomenology approach in order to explore the phenomenon in tourism destinations. Open questionnaire was used to get a comprehensive information from respondents relating competitive advantage and problems in each destination. The open questionaire is distributed to the manager and staff of 10 tourism destinations in Pasuruan city including Kakek Bodho Waterfall, Banyu Biru Natural Water Park, Bakti Alam Forest and Agriculture, Jawi Temple, Kaliandra Sejati, Grave of Mbah Semendhi, Cheng Hoo Mosque, Ranugrati Lake, Taman Dayu Water Park, and Baung Mountain. Tourism destinations in Pasuruan city consist of natural destination, city destination, religion destination, artificial or special destination, agricultural destination, culture destination and festival destination [22]. 
All of this research object represent all of the related categories. This research also captured the facilities in each destinations. This research was conducted in 2013 for 6 months (July to December).

\section{Research object}

This part describes about the brief history of each destination in Pasuruan city as a part of this research object's. Brief description of the tourism destination in Pasuruan showed in Table 1.

Table 1. Brief Description of Tourism Destinations in Pasuruan City, Indonesia

\begin{tabular}{cl}
\hline No & Tourism Destination \\
\hline 1. & Kakek Bodho Waterfall \\
& \\
\hline 2. & Banyu Biru Natural Water Park
\end{tabular}

\section{Brief Description}

Kakek Bodho waterfall is established in 1980 by local government in Pasuruan, Indonesia. This destination become a part of heritage destination because there is fenomenal story of this waterfall. Based on the local people story, in colonize era of Dutch in Indonesia there is a wisdom and patient person that known as Kakek Bodho. Kakek Bodho is a servant of Dutch family retiring to get a simple life and leave the happy thing in the world such as a monk life. He meditate in remote area and help the people in surronding area. When Kakek Bodho died, in the near of his grave is found a waterfall as the blessing for local people. Therefore, Kakek Bodho waterfall save a attractive history for local people and visitors. There are around 3050 visitor in weekdays and 200 visitors in weekend.

2. Banyu Biru Natural Water Park Banyu biru natural water park has been establish since the collonial era (before 1930s) and some of the artifact was found such as Ganesha statue and Betara Siwa statue as the symbol of Gods in Hindu's relegion. Pasuruan government renovates this destination to encourage more visitors. This detination has a deep historical background for Pasuruan citizen. Therefore, this destination is managed under the government department.

3. Bhakti Alam Forest and Agriculture Bhakti alam forest and agriculture is one of the agricultural destinations that consist of tropical fruit plantation, animal husbandry, green house, camping ground and others natural facilities. This destination becomes the preferences of some school in East Java to conduct their training program for students.

4. Jawi Temple Jawi Temple is the heritage of Singhasari Kingdom are hold in 13th century. In former, people guess that this place is a Buddhist's monastery or Hindu's temple, but the scientist conclude that this is a burial of King's Kertanegara (the last King of Singhasari).

5. Kaliandra Sejati Kaliandra Sejati is one of the international tourism destination in Pasuruan city, because there are always international visitor in each seasion. Similar with other natural destination, Kaliandra Sejati provides camping facilities based on international standard. Kaliandra Sejati was established at April 1997 by Kaliandra Foundation. Some of the program arranged in this object such as conservation of local plant, preservation of local environment and culture.

6. Grave of Mbah Semendhi Mbah Semendhi is the prominent figure of Islam in Java that originally comes from Banten, West Java, Indonesia. For Moslem people, his grave is really important especially for the history of Islam development in Indonesia. The number of visitors are among 200-300 people in weekdays and 3000-5000 people in weekend.

7. Cheng Hoo Mosque Cheng Hoo Mosque is one of the beautiful mosque in Indonesia because of the unique architecture of its. This mosque is inspired by prominent figure of Islam that orriginally comes from China, Captain Cheng Ho. Captain Cheng Ho take an expedition to Indonesia in $1404-1443$ and achor to Pandaan. This mosque use a fully chinese architectured.

8. Ranugrati Lake Ranugrati is a lake that have a historical story for Indonesian people. Ranugrati have a large area around 1,085 $\mathrm{Ha}$ and the only one lake in Indonesia that take in lowland. Based on the history, Ranugrati is created by Begawan Nyampo that angry to the local people killing his son Baru Klinting.

9. Taman Dayu Water Park

10. Baung Mountain
Taman Dayu water park was established by Ciputra.Co as one of the facilities in their property land. However, this object also become a public destination for Pasuruan people. In Taman Dayu water park there are some attractive facilities for outbond adventure. In this mountain, there are several object that can be visited such as Baung waterfall and camping facilities. Visitor can get some benefit when enjoy this object such as education, research and development, and cultivation. 


\section{RESULTS AND DISCUSSION}

This research identified several critical problems impeding the development of tourims destinations based on four categories (natural destination, cultural and religion destinations, agricultural destinations and special destinations) in rural area such as Pasuruan City, Indonesia describing as follows.

\section{Natural Destinations}

Natural tourism destinations in Pasuruan city is the potential object for tourism industries, because its have a wonderful landscape alike another similar destination in Batu city, East Java. However, it meets some critical problems constraining the development of related destinations in this categories as follow as:

$>$ There are no spesific facilities to support natural tourism destinations.

In the natural destinations, it should be prepared relating facilities for natural ad-venture such as camping ground, outbond facilities and so on. For instance, Kakek Bodho waterfall provides a complicated facilities that combining artificial facilities and natural facilities. In this case, some of the artificial facilities tend to damage the attractiveness of original destination. The management of Kakek Bodho waterfall pro-vides another artificial swimming pool and playground to attract children, but this condition tend broke brand positioning of this object.

If it is compared with Coban Rondo waterfall in Batu city, there are a significant differences between them. Coban Rondo waterfall is one of the popular destinations in Indonesia having international visitors be-cause its has a suitable additional facilities such as camping ground and outbound facilities. Management of Coban Rondo destination tries to enhance good brand positioning of their object.

$>$ There are no innovative strategy in their marketing programs.

Most of the natural destinations in Pasuruan city use government website as the only one media to promote their desti-nation. The basic reason of this condition is all of tourism management under the go-vernment department. They do not have an innitiative to broaden their marketing media.
Therefore, the number of visitor in these destination is too low compared to another natural destination in other area in Indonesia.

$>$ There are no comprehensive facilities in some of the natural destinations such as appropriate parking area and canteen. These facilities become an important consideration when someone visit a certain tourism destinations.

\section{Cultural and Religion Destinations}

Most of the tourism destinations in cultural and religion categories is heritage destination such as historical temple and grave of prominent figure in the past. In this case, these destinations become a media to learn about culture in the previous era and remember the contribution of prominent people. Some of the cultural and religion destination get a positive attention not only from local people in Pasuruan but also their visitor because they believe its destination is holy place. Therefore, they want to maintain these destinations voluntary. For instance Grave of Mbah Semendhi is one of the religion destination getting a positive attention from all people.

In other case, some of the destination did not get the similar respond and tend to forgotten by local people and visitors. Some of the visitor destroy the statue in temple and not concern about maintenance. It is ironical condition. Therefore, there are a different problem between cultural destination and religion destination describing in this part. The critical problem in cultural destinations in Pasuruan city as follow as:

1. Lack of maintenance for heritage destionation (temple) from government and visitors effecting the small number of visitors. For instance in Jawi Temple, there are only 10 to 15 visitors each day.

2. Most of the cultural destinations in Pasuruan city only have a few marketing promotion media to introduce their destinations such as twitter and facebook page. In fact, some of the media did not update for long time and only have a few information regarding the object. It is unattractive promotion strategy. Therefore, most of the visitors in some of the Pasuruan's temple comes from a local people knowing the place from their parent.

3. There are no specific management structure in the most of the cultural 
destinations. In addition, some of the destination only consist of 2 people as cleaning service employee and security employee. Therefore there are some suggestion from desti-nation's management toward government policy because they do not have representative of management.

Some of the critical problems also meet by religion tourism destinations, but it is a different problems compared to cultural destinations. It is described as follow as:

1. Most of the management team in religion destination reject the collaboration offer from their local government because they do not want to commercialize the object. They believe that religion activities should not become commercialization, eventhough government of Pasuruan city want to renovate this object based on national standard. In this case, there is untrust feeling of management team toward government policy.

2. There are no management structure managing this object. Its only have rest area for visitors after visit the grave. Management of this destionation does not have a detail future development program.

3. Most of the religion destinations in Pasuruan city only use word of mouth as their marketing media to promote their object. They tend to ignore another promotion media.

\section{Agricultural Destinations}

Agricultural tourism destination in Pasuruan city are potential destination in Indonesia because there are a lot of attractive agriculture in this city. Most of the agricultural tourism destination in Pasuruan targeted for family object. Its already have a good management system, but some of the problems still exist such as:

1. Lack of potential human resource for the position of mantaining agriculture field.

2. The are no qualified road to the location of tourism destinations. For instance, the con-dition of the road to the location of Bhakti Alam agricultural destination is really dang-erous because too many hole among of them.

\section{Special Destinations}

Most of the special tourism destinations in Pasuruan city are managed by private company. They have a good management system and structure. They also provide continuous improvement program in order to develop their tourism product and service. For instance, Kaliandra Sejati produce enzym product to do therapy treatment for the customer. Kaliandra adopt this innovation from Japanese technology. However, there are some problem that have to concern with management and local government, such as:

1. The government did not provide a good road to the location of the object. Therefore, the foundation has to make their own qualified road to attract their customer eventhough using their own budget and only several kilometers from the destination.

2. Lack of communication between management and government regarding developing program of special tourism destinations. Therefore some of the special tourism destinations not promoted yet in government website.

\section{CITY BRANDING STRATEGY}

There are many research that describe about city branding criteria to develop the popularity of the city. For instance, city branding model focus on city brand attributes, which are social bonds, business opportunities, safety, cultural activities, shopping, clean environment, nature, transport, and government services [23]. In other hand, there are mainly three approaches for promoting cities: cultural mega events, restoration and promoting heritage and the construction of iconic buildings [21,24]. In this study, city branding strategy will be offer based on the tourism destination problems in the rural area in Indonesia.

\section{Green Space Branding}

Some of the popular cities in the world have been adopt the green space branding strategy, especially in the Europe continent. Europe's Green Capital Award is a specific award for the most green city which granted by the European Union on an annual base [25]. Green in marketing science reflect to environmental policy and biophysical dimension. The environmental policy dimension concern for pollution control, reduced carbon dioxide output and limited resource consumption [26]. The biophysical di- 
mension of green celebrates the green space component of cities, highlighting the important role of urban vegetation in securing a high quality of life [27]. Based on this study, Pasuruan city as the rural area in Indonesia must create these specific activities such as:

a. Government provide a hybrid public trans-portation that having a direct access to the hotel in the city.

Therefore, domestic and international tourist can use this transportation to go to tourism destination in the city. This hybrid public transportation collaborate with local hotel and also local or national travel agent to make a complete tour program through-out tourism destinations in Pasuruan city. This program have a purpose to introduce some of the unpopular tourism destinations in Pasuruan city to the tourist.

b. Government provide a wonderful and green city park in the several area with eco and clean concept to improve the air quality in the city.

Eventhough Pasuruan have several ma-nufactures, but they must maintain the quality of environment. The number of people that concern about green concept is significantly increase year to year. Therefore this society prefer to choose the tourism destinations having a good environment.

c. Government provide a good access road not only surrounded tourism destination but also all of the area in the city.

This facilities will attract tourist to visit more places in the city such as souvernir shop and cullinary destination in the city. In this case, government can develop the local business in that area.

\section{Indentifiable Image}

When Hankinson [21] describe about construction of iconic building to promote cities, it is indicated that the city must perform the indentifiable image. These strategy is appopriate to solve the unspecific facilities problem of natural destination in Pasuruan city. Pasuruan City as the rural area in East Java has characteristic as the natural tourism city because it has many natural tourism destinations. Some of the natural destinations in Pasuruan city did not have spesific facilities conducted with the origin object. In order to strengthen the destination image, go- vernment can collaborate with tourism destination management to create a new concept of destination, particularly focus on the originality of destination object. For instance, the natural tourism destinations such as Kakek Bodho waterfall has to focus on strengtening the object. Kakek Bodho waterfall should provide the additional facilities such as outbond facilities, the adventure program, camping program and so on relating with enjoy the natural landscape. For the others destination has also to provide the suitable additional facilities such as build a museum in Jawi Temple area to attract more tourist visit that destination. Museum not only the education media but also can strengtening the heritage destination.

\section{Brand Experience}

Creating positive brand experience is one of the key success factor to attract revisiting of tourist. Government as the third parties in this industry can create a certain program collaborating among management of tourism destinations, hotels and travel agents. This program as called as city tour which create a comprehensive tourism program such as visiting natural destination, cultural destinations, special destinations and agricultural destinations. The purpose of this program is to develop all of the tourism destinations in Pasuruan City including hotel industries and travel agents industries. Regarding the transportation, travel agent can collaborate with local government using the hybird transportation vehicle. Comprehensive city tour program will increase a positive experience of tourist and encourage them to give positive recommendation to other parties to visit Pasuruan city. Tourism destinations management and government also have to provide an innovative marketing strategy such as creating the own website and active information about their object.

\section{CONCLUSION}

Based on this research, we found some of the critical problems in Pasuruan's tourism destination including: (1) there are no specific support facilities in natural tourism destination; (2) there are no innovative marketing strategy to introduce tourism destination; and also (3) lack of communication between management and local government in order to manage related tourism destinations. The main strategy to evaluate these problems are city branding strategy which is focus on green space branding, identifiable image 
and brand experience. The green space branding strategy consist of providing hybrid transportation, green city park and good access road. In addition, identifiable image could be created through promoting originality of tourism object. Furthermore, positive brand experience of local and international tourist can be build by comprehensive city tour program.

\section{ACKNOWLEDGEMENTS}

The authors would like to thanks the Tourism Department of Pasuruan City, East Java, Indonesia for the official permission did this research in all of the selected tourism destinations in Pasuruan and also to the managers of all related tourism destinations in Pasuruan who give the detail information regarding their condition toward the researchers.

\section{REFERENCES}

[1] Gracia, J. A., M. Gomez and A. Molina. 2012. A destination branding model: an empirical analysis based on stakeholders. Tourism Management 33, 646-661.

[2] BPS. 2015. Indonesia in Figure, 2015. Center of Statistic. Jakarta.

[3] Mathieson, A. and G. Wall. 1982. Tourism: economic, physical, and social impacts. Longman House. New York.

[4] Ifad. 2015. Investing in rural people in Indonesia. International Fund for Agricultural Development. Available at: ifad.org.

[5] Roberts, L. and D. Hall. 2001. Rural tourism and recreation: principles to practice. $C A B I$ publishing.

[6] Pasuruankab. 2014. Gambaran umum. Government of Pasuruan Regency. Available at: pasuruankab.go.id.

[7] Anholt, S. 2010. Places: identity, image and reputation. Palgrave MacMillan. Houndmills.

[8] Freire, J. R. 2005. Geo-branding, are we talking nonsense? a theoretical reflection on brands applied to places. Place Branding 1(4), 347-362.

[9] Zhang, L. and S. X. Zhao. 2009. City branding and the Olympic effect: a case study of Beijing. Cities 26(5), 245-254.

[10] Sevin, H. E. 2014. Understanding cities through city brands: city branding as a social and semantic network. Cities 38, 47-56.

[11] Ritchie, B. J. R. and R. J. B. Ritchie. 1998. The branding of tourism destinations: past achievements and future challenges. Paper of Annual Congress of the International As- sociation of Scientific Experts in Tourism, Destination Marketing: Scopes and Limitations.

[12] Esu, B. B. and V. M. Arrey. 2009. Branding cultural festival as a destination attraction: a case study of Calabar Carnival Festival. International Business Research 2(3),182-192.

[13] Cai, L. A. 2002. Cooperative branding for rural destinations. Annals of Tourism Research 29(3), 720-742.

[14] Morrison, A. and D. Anderson, 2002. Destination branding. Available at: http://www. macvb.org/intranet/presentation/Destinati onBrandingLOzarks6-10-02.ppt.

[15] Florek, M., A. Insch and J. Gnoth. 2006. City council websites as a means of place brand identity communication. Place Branding 2(4), $276 \mathrm{e} 296$.

[16] Nandan, S. 2005. An exploration of the brand identity-brand image linkage: a communications perspective. Brand Management 12(4), 264e278.

[17] Ryan, C. and H. Gu. 2008. Destination branding and marketing: the role of marketing organizations. In: Oh, H. (Ed.). Handbook of hospitality marketing management. Butterworth-Heinemann. Oxford. 383e411.

[18] Um, S. and J. Crompton. 1990. Attitude determinants in tourism destination choice. Annals of Tourism Research 17(3), 432e448.

[19] Pike, S. 2005. Tourism destination branding complexity. Journal of Product and Brand Management 14(4), 258e259.

[20] Zenker, S. and E. Braun. 2010. Towards an integrated approach for place brand management. Paper of 50th European Regional Science Association Congress. Jönköping, Sweden.

[21] Hankinson, G. 2006. The management of destination brands: five guiding principles based on recent developments in corporate branding theory. Brand Mangagement 14(3), 240-254.

[22] Tourism and Cultural Department of Pasuruan City. 2015. Info wisata. Available at: disbudpar.pasuruankab.go.id.

[23] Merrilees, B., D. Miller, C. Herington. 2009. Antecedents of residents' city brand attitudes. Journal of Business Research 62(3), 362-367.

[24] Kavaratzis, M. 2005. Branding the city through culture and entertainement. AESOP 05, Vienna.

[25] European Green Capital Award. 2012. Available at: http://www.hamburg.de/content 
blob/1251348/data/10-green-capital-eu-

broschuere-en.pdf.

[26] Kahn, M. 2006. Green cities: urban growth and the environment. Brookings Institution Press, Washington, D.C.

[27] Beatley, T. 2011. Biophilic cities: integrating nature into urban design and planning. Is|and Press. Washington, D.C. 